\title{
Plant Growth Promoting Rhizobacteria Pseudomonas: A Review
}

\author{
Stanzin Dorjey ${ }^{1}$, Disket Dolkar ${ }^{2 *}$ and Richa Sharma ${ }^{2}$ \\ ${ }^{1}$ Sher-e-Kashmir University of Agricultural Sciences and Technology \\ of Kashmir, Wadura Sopore, 193201, Kashmir, India \\ ${ }^{2}$ SKUAST-Jammu Chatha-180009 \\ *Corresponding author
}

\begin{tabular}{|c|c|}
\hline & A B S T R A C T \\
\hline Keywords & \\
\hline $\begin{array}{l}\text { Plant Growth- } \\
\text { Promoting } \\
\text { Rhizobacteria } \\
\text { (PGPR), } \\
\text { Pseudomonas. } \\
\text { Article Info }\end{array}$ & \multirow{2}{*}{$\begin{array}{l}\text { Plant Growth-Promoting Rhizobacteria (PGPR) are naturally occurring soil } \\
\text { bacteria that can enhance plant growth by wide variety of mechanisms. } \\
\text { PGPR offers an attractive way to replace chemical fertilizer, pesticides, and } \\
\text { supplements. Agriculture and horticulture crops inoculated with certain } \\
\text { PGPR strains may result in multiple effect right from enhancement of } \\
\text { seedling germination to vegetative growth to yield. }\end{array}$} \\
\hline $\begin{array}{l}\text { Accepted: } \\
\text { 17 June } 2017\end{array}$ & \\
\hline $\begin{array}{l}\text { Available Online: } \\
10 \text { July } 2017\end{array}$ & \\
\hline
\end{tabular}

\section{Introduction}

Plant growth promoting rhizobacteria (PGPR), a group of root associated bacteria, intimately interact with the plant roots and consequently influence plant health and soil fertility. They offer an excellent combination of traits useful in disease control and plant growth promotion. Plant growth promoting rhizobacteria (PGPR) were first defined by Kloepper and Schroth (1978) as the soil bacteria that colonize the roots of plants. Amongst the PGPRs, fluorescent pseudomonads have emerged as the largest and potentially the most promising group of PGPR with their rapid growth, simple nutritional requirements, ability to utilize diverse organic substrates and mobility.
Fluorescent pseudomonads produce highly potent broad spectrum antifungal molecules against various phytopathogens, thus acting as effective bio control agents.

Pseudomonas species are ubiquitous bacteria in agricultural soils and have many traits that make them well suited as PGPR. Fluorescent pseudomonads are gram negative, aerobic rods, motile with polar flagella and have the ability to produce water soluble yellow green pigment (Palleroni et al., 1973). They comprise the species of $P$. fluorescens (four bio types), $P$. putida (two bio types), $P$. aeruginosa, $P$. chlororaphis, $P$. aureofaciens and $P$. syringe (Schippers et al., 1987). They are well adapted to rhizosphere and 
rhizoplane, have a fast growth rate in the rhizoplane and are able to utilize a large number of organic substrates (Stolp and Godkari, 1981) including root exudates (Rovira and Davey, 1974). The worldwide interest in this group of rhizobacteria was sparked off by the studies initiated at the University of California, Berkeley, USA during 1970s. Fluorescent pseudomonads exhibit diverse mechanisms of biocontrol which include antibiosis, HCN production, siderophore production, competition for space and nutrients and induced systemic resistance. PGPR are known to induce resistance against fungal, bacterial, viral diseases and insect pests (Chen et al., 2000).

The crucial factor in the success of biological control by fluorescent pseudomonads is their ability to colonize the rhizosphere and their persistence throughout the growing season, because they occur in the natural habitat of rhizosphere and when they are reintroduced to roots through seed or seed-piece inoculation, they colonize root surface profusely (VanLoon et al., 1998). Fluorescent pseudomonads exert a protective effect on the roots through antagonism against phytopathogenic fungi and bacteria (Dwivedi and Johri, 2003) by suppressing the pathogens adopting various modes of actions. Fluorescent pseudomonads are known to produce plant growth promoting substances like, auxins, gibberellins, cytokinines etc (Suneesh, 2004).

\section{Biocontrol activity mediated by the synthesis of allelochemicals}

Plant growth promoting rhizobacteria (PGPR) colonization and defensive retention of rhizosphere niches are enabled by production of bacterial allelochemicals, including ironchelating siderophores and antibiotics.

\section{Siderophore}

Siderophores are low molecular weight ferric iron chelating compounds that are secreted extracellularly under iron limiting conditions and whose main function is to supply iron to the iron starved cells. Under iron-limiting conditions plant growth promoting rhizobacteria produce low-molecular-weight compounds called siderophores to competitively acquire ferric ion (Whipps, 2001). Siderophores are small, high-affinity iron chelating compounds secreted by microorganisms such as bacteria and fungi (Miller, 2008). Pseudomonas siderophores have a high affinity for iron, and when they chelate this micro-nutrient, they make it less available for other micro-organisms, including plant pathogens. This mechanism is considered indirect plant growth promotion by Pseudomonas. Pseudomonas can synthesise siderophores in iron limiting conditions. It is known that compounds such as siderophores are synthesised mainly during the exponential growth phase, which is the stage in which the population requires more nutrients for cell division (O'Sullivan and O'Gara, 1992). Likewise, the pseudobactin Fe complex has a high stability constant (Chen et al., 1994), suggesting that virtually all excreted pseudobactin molecules bind to $\mathrm{Fe}$ present in the medium (Loper and Henkels, 1999). Therefore, in microenvironments such as the rhizosphere, the synthesis of siderophores is important to confer an advantage in the competition for nutrients and space (Loper and Henkels, 1999). Synthesis of iron-chelating compounds, such as siderophores, by Pseudomonas is a characteristic feature visible in some isolates from bulk or rhizosphere soils. In culture media with trace amounts of iron, a yellowgreen halo can be observed, which may be fluorescent under ultraviolet light (Budzikiewicz, 1993). Kloepper et al., (1980b) proposed that siderophores might be involved in biocontrol of plant pathogens and in plant growth promotion. Since then, the role of siderophores as chelating agents depriving soil pathogens of iron, an essential 
element for growth without which the survival of many micro-organisms is affected, has been widely recognised (Loper and Henkels, 1999). Some PGPR strains produce siderophores that bind $\mathrm{Fe}^{3+}$, making it less available to certain members of native microflora (Kloepper et al., 1980a). The strains of rhozobacteria that produce siderophore under Fe limiting conditions in the rhizosphere chelate $\mathrm{Fe}^{3+}$, the form that is insoluble in water, hence not available to bacteria. Isolates belonging to P. fluorescens were reported to produce extracellular siderophores when grown in Chrome azurol $\mathrm{S}$ under iron deficiency (Suryakala et al., 2004). Instant golden yellow colour is a positive test for siderophore production on succinate medium and casamino acid medium (CAA). Most evidences to support the siderophore theory of biological control by rhizobacteria comes from the work with pyoverdin, a class of siderophores that comprise the fluorescent pigment of fluorescent pseudomonads (Demange et al., 1987). Suryakala et al., (2004) suggested that tri-hyobroxamate siderophores might be exploited as potent biocontrol compounds against plant pathogens.

\section{Antibiosis}

Antibiosis has been postulated to play an important role in disease suppression by rhizobacteria (Gutterson et al., 1986). Pseudomonads suppress the soil-borne fungal pathogens by producing antifungal metabolites such aspyoluteorin, pyrrolnitrin, phenazines and 2, 4-di-acetyl phloroglucinol (Deepti and Johri 2003).The compound 2,4diacetylphloroglucinol (DAPG) is a phenolic molecule produced by certain plant-associated fluorescent pseudomonads of worldwide origin (Thomashow et al., 1997). Antibiosis is now often implicated as an important mechanism of biological control, resulting from the fact that it is an attractive mechanism to study and can provide a highly effective mode of action (Handelsman and Stabb, 1996). Pseudomonas known to produce the antibiotic 2, 4diacetylphloroglucinol (DAPG) may also induce host defences. Additionally, DAPGproducer bacterial antagonists can aggressively colonize root, a trait that might further contribute to their ability to suppress pathogen activity in the rhizosphere of plant through competition for organic nutrients (Heydari and Pessarakli, 2010).Antimicrobial compounds produced by Pseudomonas cepacia were reported to inhibit the radial growth of some important soil borne pathogens like $F$. oxysporum, Macrophomina phaseolina, Sclerotium rolfsii, $R$. solani, and Pythium ultimum (Baligh et al., 1999).

Several strains of fluorescent pseudomonad produce antifungal metabolites namely phenazines which comprise of a large family of heterocyclic nitrogen containing coloured pigment with broad spectrum antibiotic activity (Thomashow et al., 1997). Pyrrolnitrin (PRN) [3-chloro-4-(2'-nitro-3'chloro-phenyl) pyrrole] is another broadspectrum antifungal metabolite produced by many fluorescent and non-fluorescent strains of the genus Pseudomonas. A phenyl pyrrol derivative of PRN has been developed as an agricultural fungicide. Pyrrolnitrin persists actively in the soil for at least 30 days, it does not readily diffuse and is released only after lysis of host bacterial cell (Radjacommare et al., 2004). The biological control agent, $P$. fluorescens BL915 is reported to contain four gene clusters involved in the biosynthesis of antifungal molecule PRN from the precursor tryptophan (Hamill et al., 1970). The broadspectrum activity of pyrrolnitrin, produced by Pseudomonas and Burkholderia species was noticed by Nishida et al., (1965) who tested and further developed this antibiotic for therapeutic purposes against human pathogenic bacteria and fungi. With respect to 
plant pathogenic fungi, pyrrolnitrin has shown activity against a wide range of Basidiomycetes, Deuteromycetes and Ascomycetes, including several economically important pathogens like Rhizoctonia solani, Botrytis cinerea, Verticillium dahliae and Sclerotinia sclerotiorum (Ligon et al., 2000).

Hydrogen cyanide ( $\mathrm{HCN})$ is produced by many rhizobacteria and is postulated to play a role in biological control of pathogens (Defago et al., 1990). Voisard et al., (1989) presented evidence that $\mathrm{HCN}$ was involved in biological control by Pseudomonas flourescens strain CHA0 which stimulated root hair formation, indicating that the strain induced altered plant physiological activities. Ramette et al., (2003) reported that HCN was a broad spectrum antimicrobial compound involved in biological control of root diseases by many plant associated fluorescent pseudomonads. HCN inhibits the electron transport there by energy supply to the cells is disrupted leading to the death of the organism. It affects the proper functioning of the enzymes and natural receptors by reversible mechanisms of inhibition (Corbett, 1974). It is also known to inhibit the action of cytochrome oxidase (Gehring et al., 1993).

\section{Indirect plant growth promotion through induced systemic resistance}

Biopriming plants with some PGPR can also provide systemic resistance against a broad spectrum of plant pathogens. Diseases of fungal, bacterial and viral origin and in some instances even damage caused by insects and nematodes can be reduced after application of PGPR (Ryu et al., 2004).

\section{Induced systemic resistance}

Induced systemic resistance is broadly defined as activation of latent defence mechanisms in plants prior to pathogenic attack. The mechanism has been hypothesized to be an operable mechanism in several rhizobacterial systems. Induced systemic resistance is associated with increased synthesis of certain enzymes such as peroxidase (Langrimini and Rothstein, 1987), increased levels of certain acid soluble proteins (Zdor and Anderson, 1992) and the accumulation of phytoalexins in the induced plant tissue (Vanpeer et al., 1991). The seed bacterization of common bean with $P$. fluorescens S97 was reported to suppress the halo blight caused by $P$. syringe pv. phaseolicola through induced systemic resistance mechanism (Alstrom, 1991).

\section{Influenced of PGPR on agricultural crops}

Tomato, cucumber, lettuce and potato plants bacterized with plant growth promoting Pseudomonas strain have shown increased root and shoot fresh weight and simultaneous suppression of deleterious pathogenic microflora (Vanpeer and Schippers, 1989). Walley and Germida (1997) observed enhancement of shoot dry weight from 16 to 48 per cent and root dry weight from 82 to 137 per cent when inoculated with fluorescent pseudomonads. Gupta et al., (2002) reported that peanut seeds bacterized with PseudomonasGRC2 showed a significant increase in germination (83\%) under field conditions. Pseudomonas do not form a symbiosis similar to that formed by rhizobia with plants, although they are able to penetrate plant tissues and establish themselves as endophytes (MarquezSantacruz et al., 2010). Inside the plant, they also play an important role as PGPR and inhibit pathogen growth by various mechanisms. By competition and production of antimicrobial compounds, PGPR can reduce populations of plant pathogens and deleterious rhizobacteria, which restrict plant growth. Some of these disease-suppressing activities, such as production of $\mathrm{HCN}$ can reduce plant growth as well, but more often 
the net effect is improved plant development, resulting in more vigorous growth and increased yield of agricultural crops (Dowling and O'Gara, 1994). The species of fluorescent pseudomonads are grouped into different biovars and subgroups based on similarity in biochemical tests (Barett et al., 1986). Thus, rapid identification of potentially and economically viable bioagents is possible through various methods of biochemical characterization (Weller et al., 2002).

Various phenotypic and biochemical methods have been developed and used for characterizing pseudomonad isolates. Most of the tests conducted for identification of fluorescent pseudomonas have been based on physiological and nutritional tests (Holt et al., 1984). Most of the plant associated Pseudomonas spp. belong to $P$. fluorescens and $P$. putida complex and there has been no clear distinction between the two (Sheath et al.,1981). However, these two species are identified based on trehalose utilization and gelatine liquefaction. In this, $P$. fluorescens exhibits positive for both the tests, whereas, $P$. putida shows negative response (Hildebrand et al., 1992). P. fluorescens B16 is a plant growth-promoting rhizobacterium and produces pyrroloquinoline quinone which is a plant growth promotion factor (Choi et al., 2008). Burr et al., (1978) reported that strains of $P$. fluorescens and $P$. putida applied to seed tubers improved the growth of potato. These findings were confirmed and later exemplified in the tomato and eggplant (Kumar and Dubey, 1993), and lentil (Rao et al., 1999). Vrany and Fiker (1984) recorded 4 to 30 per cent improvement in plant growth and tuber yield of potato inoculated with $P$. fluorescens under field conditions. Introduction of sss gene encoding rhizosphere colonization ability into poor colonizer strain of P. fluorescens WCS 307 has exhibited increased competitive rhizosphere colonization ability in tomato roots resulting in increased protection against $F$. oxysporum f.sp. radicis-lycopersici (Dekkers et al., 2000). The fluorescent pseudomonads in addition to their ability to aid plant growth promotion are also good biocontrol agents. They have emerged as the biggest and potentially the most promising group amongst the PGPRs involved in biocontrol of diseases. $P$. fluorescens is adapted to survival in soil and colonization of plant roots and this applies also to the particular case of biocontrol agents from this species (Kiely et $a l .$, 2006). Biocontrol strains have noticeably been observed at the root surface, (i.e. the rhizoplane) often forming micro colonies or discontinued bio films in the grooves between epidermal cells. Certain strains are also capable of endophytic colonization. Within root tissues, they are mostly found in the intercellular spaces of the epidermis and the cortex (Duijff et al., 1997). They are effective in utilizing seed and root exudates for growth and can colonize the rhizosphere aggressively. Strains with biocontrol ability may represent in the order of 10 per cent of all rhizosphere strains and they have been isolated from a very wide range of soils, climatic regions and host plants (Rezzonico et al., 2007). There are several species of Pseudomonas which are effective antagonists of fungal pathogens and act as plantpromoting rhizobacteria (De Curtis et al., 2010), a strain of Pseudomonas fluorescens was reported to have antagonistic property against Rhizoctonia solani (Howell and Stipanovic, 1979).

Studies have indicated that seed treatment with $P$. fluorescens isolate 63-28 prevented the entry of Fusarium wilt pathogen ( $F$. oxysporum f. sp. lycopersici) in the vascular tissue by strengthening cell wall structures and accumulation of phenolic substances and chitinases (M'Piga et al.,1997). Pseudomonas sp. RSB29 showing significant inhibition of fungal pathogens such as $F$. oxysporum $\mathrm{f}$. sp. ciceri RS1, Macrophomina phaseolina RSB9, Fusarium udum RSB19, Fusarium solani 
RSB38 and $R$. solani BH49 has been reported by Saikia et al., (2004). Fusarium wilts have been reported to be suppressed by the activity of species and non pathogenic strains of $F$. oxysporum by Boer et al., (2003).

Studies implies that prior application of fluorescent pseudomonads strengthen host cell wall structures resulting in restriction of pathogen invasion in plant tissue (Chen et al., 2000). The study also indicated that a PO1 isoform was prominently expressed in $P$. fluorescens isolate Pf1-treated root tissues against $F$. oxysporum f. sp. lycopersici. This unique isoform induced by $P$. fluorescens isolate Pf1 might have contributed to induced defense in tomato root tissue against the invasion by $F$. oxysporum f. sp. lycopersici. Accumulation of phenolics, PAL, $\beta-1,3$ glucanase and induction of PO1 isoform, PPO1 and PPO2 isoforms and Chi2 isoform by $P$. fluorescens isolate Pf1 in tomato root tissues might have collectively contributed to induced resistance in tomato plants against $F$. oxysporum f. sp. lycopersici.

Like Bacillus, Pseudomonas also induces systemic resistance in plants. Studies have reported that $P$. fluorescens EP1, $P$. putida 5-48 and $P$. fluorescens can protect sugarcane, oak and tomato plants from pathogens such as Colletotrichum falcatum, Ceratocystis fagacearum and $F$. oxysporum, respectively. $P$. fluorescens isolates were obtained from the rhizosphere, checked for their in vitro antagonistic activity, formulated and evaluated for their ability to control Fusarium wilt and promote growth of tomato plants under greenhouse conditions. The fresh cultures of $P$. fluorescens isolate increased seedling emergences up to 90 per cent, when compared to the control in pots (Asha et al., 2011). The results indicated that there was no negative effect when the $P$. fluorescens was applied as biocontrol agent, on the contrary they exhibited synergism in promoting crop growth and yield of tomato besides controlling the Fusarium wilt disease. Efri (1994) reported that, P. fluorescens could inhibit the development of tomato wilt by
71.7 per cent compared to plants without application of the bacteria. In the laboratory test, appearance of empty zone in the Petri dish that contained $F$. oxysporum and $P$. Fluorescens was observed, proving that there was a competition between the parasitic pathogen and the antagonistic pathogen for iron, because $P$. fluorescens has a high affinity to bind iron. The bacterium takes the iron and binds it to its necessity, thus $F$. oxysporum lacks the iron for its proliferation and development of the disease is suppressed. The reduction of pathogenic activity of $F$. oxysporum by pseudomonads could also be related to the detoxification of fusaric acid (Harbone, 1983). Peitr (1991) reported that $P$. fluorescens suppressed Fusarium wilt by detoxifying the culture filtrates of different Fusarium species and inactivating the enzymes from the fungal cultures. Borowitz et al., (1992) reported that extracellular proteases of $P$. fluorescens strains were able to inactivate hydrolases and phytotoxins of phytopathogenic Fusarium spp. The talc and sodium alginate formulations of $P$. fluorescens was recommended to the farmers as one of the crop protection strategies for the management of Fusarium wilt of tomato and this practice was also extended to other crops by Asha et al., (2011).

\section{References}

Alstrom, S. 1991. Induction of disease resistance in common bean susceptible to halo blight bacterial pathogen after seed bacterization with rhizosphere Pseudomonas. J. Gen. Appl. Microbiol., 37: 495-501.

Asha, B.B., Chandra, N.S., Shankar, U.A.C., Srinivas, C. and Niranjana, S.R. 2011. Biological control of $F$. oxysporum $\mathrm{f}$. sp. lycopersici causing wilt of tomato by Pseudomonas fluorescens. Int. J. Microbiol. Res., 3: 79-84.

Baligh, M., Delgado, M. A. and Conway, K. E. 1999. Evaluation of Burkholderia cepacia strains: root colonization of Catharanthus roseus and in vitro inhibition of selected 
soil borne fungal pathogen. In: Proceedings of Oklahoma Academic Science, 79:19-27.

Barett, E. L., Solanes, R. E., Tang, J. S. and Palleroni, N. J. 1986. Pseudomonas fluorescens, its resolution into distinct component groups and relationship of these to other $P$. fluorescens biovars to $P$. putida and to psychrophilic pseudomanads associated with food spoilage. J. Gen. Microbiol., 130: 27092721.

Boer, W. D., Verheggen, P., Gunnewiek, P. J. A., Kowalchuk, G. A. and Veen, G. A. 2003. Microbial community composition affects soil fungistasis. Appl. Environ. Microbiol., 69: 535-544.

Borowitz, J. J., Stankie-Dicz, M., Lewicka, T. and Zukowska, Z. 1992. Inhibition of fungal cellulase, pectinase and xylanase activity of plant growth promoting fluorescent pseudomonads. Bull. OILB/SROP, 15: 103-106.

Budzikiewicz, H. 1993. Secondary metabolites from fluorescent pseudomonads. FEMS Microbiology Reviews, 10: 209-228.

Burr, T. J., Schroth, M. N. and Suslow, T. 1978. Increased potato yields by treatment of seed pieces with specific strains of Pseudomonas fluorescens and $P$. putida. J. Phytopatho, 68: 1377-1383.

Chen, C., Be-langer, R. R., Benhamou, N. and Paulitz,T. C. 2000. Defense enzymes induced in cucumber roots by treatment with plant growth-promoting rhizobacteria (PGPR) and Pythium aphanidermatum. Physiol. Mol. Plant Pathol., 56: 13-23.

Chen, Y., Jurkevitch, E., Bar-Ness, E. and Hadar, Y. 1994. Stability constants of pseudobactin complexes with transition metals. Soil Sci. Soc. Am. J., 58: 390-396.

Choi, O., Kim, J., Jeong, Y., Moon, J. S., Park, C. S. and Hwang, I. 2008. Pyrroloquinoline Quinone is a plant growth promotion factor produced by Pseudomonas fluorescens B16. Plant Physiol., 146: 657-668.

Corbett, J. R. 1974. Pesticide design. In:
Voisard, C. (eds.). The Biochemical Mode of Action of Pesticides pp 44-86. Academic Press, Inc, London.

De-Curtis, F., Lima, G., Vitullo, D. and DeCicco, V. 2010. Biocontrol of Rhizoctonia solani and Sclerotium rolfsii on tomato by delivering antagonistic bacteriathrough a drip irrigation system. Crop Prot., 29: 663-670.

Deepti, D. and Johri, B. N. 2003. Antifungals from fluorescent pseudomonads: biosynthesis and regulation. Curr. Sci., 85: 1693-1703.

Defago, G., Berling, C. H., Borger, U., Keel, C. and Voisard, C. 1990. Suppression of black rot of tobacco by a Pseudomonas strain: Potential applications and mechanisms, In: Hornby, D., Cook, R. J. and Henis, Y. (eds.). Biological Control of Soil Borne Plant Pathogen. CAB International, pp. 93-108.

Dekkers, L. C., Mulders, I. H. M., Phoelich, C. C., Chin, A., Woeng, T. F. C., Wijfjes, A. H. M. and Lugtenberg, B. J. J. 2000. The colonization gene of the tomato-Fusarium oxysporum f.sp. radicis-lycopersici biocontrol strain Pseudomonas fluorescens WCS 365 can improve root colonization of other wild-type Pseudomonas spp. bacteria. Mol. PlantMicrobe Interac., 13: 1177-1183.

Demange, P., Wendenbaum, S., Bateman, A., Dell, A. and Abdallah, M. A. 1987. Bacterial siderophores: Structure and physicochemical properties of pyoverdins and related compounds. In: Winkleman, G., Van-der, H. D. and Neilands, J. B. (eds.). Iron Transport in Microbes, Plants and Animals, VCH chemie, Weinheim,pp. 167-187.

Dowling, D. N. and O'Gara, F. 1994. Metabolites of Pseudomonas involved in the biocontrol of Plant Disease. Trends Biotechnol., 12: 133-141.

Duijff, B. J., Gianinazzi, P. V. and Leemanceau, P. 1997. Involvement of the outer membrane lipopolysaccharides in the endophytic colonization of tomato roots by biocontrol Pseudomonas fluorescens 
WCS417r. New Phytol., 135: 325-334.

Dwivedi, D. and Johri, B. N. 2003. Antifungals from fluorescent pseudomonads: Biosynthesis and regulation. Curr. Sci., 85: 1693-1703.

Efri, S. 1994. Analisis Aplikasi Pseodomonads kelompok fluorescens dan Trichoderma viridae Pers. Ex Gray untuk pengendalian layu fusarium pada tomat (Application analysis of fluorescent pseudomonads and Trichoderma viride Pers. Ex. Gray to control tomato Fusarium wilt disease). M. Sc. thesis, Bogor Institute of Agriculture.

Gehring, P. J., Noton, R. J. and Watanabe, P. G. 1993. Solvents, fumigants and related compounds. In: Hayer, W. J. and Laws, E. R. (eds.). Handbook of Pesticides Toxicology. pp 646-649. Academic Press, Inc, San Diego, California,

Gupta, A., Meyer, J. M. and Goel, R. 2002. Development of heavy metal resistant mutants of phosphate solubilizing Pseudomonas sp. NBRI 4014 and their characterization. Curr. Microbiol., 45: 323-327.

Gutterson, N., Layton, T. J. and Warren, G. J. 1986. Molecular cloning of genetic determinants for inhibition of fungal growth by a fluorescent pseudomonad. $J$. Bacteriol, 165: 696-703.

Hamill, R. L., Elander, R. P., Mabe, J. A. and Gorman, M. 1970. Metabolism of tryptophan by Pseudomonas aureofaciens. III. Production of substituted pyrrolnitrins from tryptophan analogues. App. Microbiol, 19: 721-725.

Handelsman, J. and Stabb, E. V. 1996. Biocontrol of soil borne plant pathogens. Plant Cell, 8: 1855-1869.

Harbone, J. B. 1983. Toxins of plant fungal interactions. In: Keeler R.F. (eds.). Plant Fungal Toxins. pp 743-782. Marcel Dekker, New York.

Heydari, A. and Pessarakli, M. 2010. A review on biological control of fungal plant pathogens using microbial antagonists. $J$. Biol. Sci., 10: 273-290.

Hildebrand, D. C., Schroth, M. N. and Sand, D.
C. 1992. Pseudomonas. In: Schad, N. W. (eds.). Laboratory guide for identification of plant pathogenic bacteria. pp 60-80. International Book Distributing Co. Lucknow.

Holt, J. G., Kreig, N. R., Sneath, P. H. A., Staley, J. T. and Williams, S. T. 1984. Bergey's Mannual of Determinative, pp. 750-770.Williams and Wilkins, Baltimore and London.

Howell, C. R. and Stipanovic, R. D. 1979. Control of Rhizoctonia solani on cotton seedlings with Pseudomonas fluorescens and with an antibiotic produced by the bacterium. Phytopathology., 69: 480-482.

Kiely, P. D., Haynes, J. M., Higgins, C. H., Franks, A., Mark, G. L., Morrissey, J. P. and O'Gara, F. 2006. Exploiting new systems-based strategies to elucidate plant-bacterial interactions in the rhizosphere. Microbiol. Ecol., 51: 257266.

Kloepper, J. W. and Schroth, M. N. 1978. Plant growth promoting rhizobacteria on radishes. In Station de pathologie vegetale et phyto-bacteriologie (ed.), Proceedings of the 4th International Conference on Plant Pathogenic Bacteria, vol. II. Gilbert Clarey, Tours, France, 879-882

Kloepper, J. W., Leong, J., Teintze, M. and Schroth, M. N. (1980a). Pseudomonas siderophores: A mechanism explaining disease suppressive soils. Curr. Microbiol., 4: 317-320.

Kloepper, J. W., Leong, J., Teintze, M. and Schroth, M. N. (1980b). Enhanced plant growth by siderophores produced by plant growth-promoting rhizobactria. Nature, 286: 885-886.

Kumar, B. S. and Dubey, H. S. 1993. Siderophore production by a plant growth promoting fluorescent pseudomonad RBT13. Indian J. Microbiol., 33: 61-65.

Langrimini, L. M. and Rothstein, S. 1987. Tissue specificity of tobacco peroxidase isoenzyme and their induction by wounding and tobacco mosaic virus infection. Plant Physiol., 84: 438-442.

Ligon, J. M., Hill, D. S., Hammer, P. E., 
Torkewitz, N. R., Hofman, D., Kempf, H. J. and VanPee, K. H. 2000. Natural products with antifungal activity from Pseudomonas biocontrol bacteria. Pest Manag. Sci., 56: 688-695.

Loper, J. E. and Henkels, M. D. 1999. Utilization of heterologous siderophores enhances levels of iron available to Pseudomonas putida in the rhizosphere. Appl. Environ. Microbiol., 65: 53575363.

M'Piga, P., Belanger, R. R., Paulitz, T. C. and Benhamou, N. 1997. Increased resistance to Fusarium oxysporum f. sp. radicislycopersici in tomato plants treated with the endophytic bacterium Pseudomonas fluorescens strain. Physiol. Mol. Plant Pathol., 50:301-320.

Marquez-Santacruz, H. A., Hernandez-Leon, R., Orozco-Mosqueda, M. C., VelazquezSepulveda, I. and Santoyo, G. 2010. Diversity of bacterial endophytes in roots of Mexican husk tomato plants (Physalis ixocarpa) and their detection in the rhizosphere. Genet Mol. Res., 9: 23722380.

Miller, M. J, 2008. Siderophores (microbial iron chelators) and siderophore-drug conjugates (new methods for microbially selective drug delivery). M. Sc. thesis, University of Notre Dame.

Nishida, M., Matsubara, T. and Watanabe, N. 1965. Pyrrolnitrin, a new antifungal antibiotic. pp. 17-24. In: NowakThompsan, B., Gould, S. J. and Loper, J. E. (eds.). Characterization of the Pyoluteorin Biosynthetic Gene Cluster of Pseudomonas fluorescens Pf-5, Gene, Vol-4. Spinger Verlag.

O'Sullivan, D. J. and O'Gara, F.1992. Traits of fluorescent Pseudomonas spp. involved in suppression of plant root pathogens. Microbiol. Rev., 56: 662-676.

Palleroni, N. J., Kunisawa, R. and Contopoulo, R. 1973. Nucleic acid homologies in the genus, Pseudomonas. Int J. Syst. Bacteriol, 23: 333-339.

Peitr, S. J. 1991. Inhibition of culture filtrate toxicity and hydrolase activity of phytopathogenic Fusarium spp. by plant growth promoting Pseudomonas fluorescens. pp. 147-151. In: Keel, C., Koller, B. and Defago, G. (eds). Plant Growth-Promoting Rhizobacteria, Progress and Prospects 10 BC/WPRS.

Radjacommare, R., Nandakumar, R., Kandan, A. and Samiyappan, R. 2004. Association of the hydrolytic enzyme chitinase against Rhizoctonia solani in rhizobacteria treated rice plants. J. Phytopathol, 153: 36-43.

Ramette, A., Moenne, L. Y. and Defago, G. 2003. Prevalence of fluorescent pseudomonads producing antifungal phloroglucinols and/or hydrogen cyanide in soils naturally suppressive or conducive to tobacco black root rot. FEMS Microbiol Ecol., 44: 35-43

Rao, V. S., Sachan, I. P. and Johri, B. N. 1999. Influence of fluorescent pseudomonads on growth and nodulation of lentil (Lens esculentus) in Fusarium infested soil. Indian J. Microbiol, 39: 23-29

Rezzonico, F., Zala, M., Keel, C., Duffy, B., Moenne, L. Y. and Defago, G. 2007. Is the ability of biocontrol fluorescent pseudomonads to produce the antifungal metabolite 2,4-diacetylphloroglucinol really synonymous with higher plant protection. New Phytologist, 173: 861872.

Rovira, A. D. and Davey, C. B. 1974, Biology of the rhizosphere. pp. 153-204. In: Carson, E.W.(eds.). The Plant Root and its EnvironmentVol-1. University Press of Virginia.

Ryu, C. M., J. F. Murphy, K. S. Mysore, and J. W. Kloepper. 2004. Plant growthpromoting rhizobacterial systemically protect Arabidopsis thaliana against Cucumber mosaic virus by a salicylic acid and NPR1-independent and jasmonic acid-dependent signaling pathway. The Plant J. 39:381-39

Saikia, R., Singh, K. and Arora, D. K. 2004. Suppression of Fusarium-wilt and charcoal rot of chickpea by Pseudomonas aeroginosa RsB29. Indian J. Microbiol., 44: $181-184$ 
Schippers, B., Bakker, A. W. and Bakker, A. H. M. 1987. Interactions of isolates and beneficial rhizosphere microorganism and the effect of cropping practice. Annu. Rev. Phytopathol., 25: 339-338.

Sheath, P. H. A., Stevens, M. and Sackin, M. J. 1981. Numerical taxonomy of Pseudomonas based on published records of substrate utilization. Anton. Van Leeuw., 47: 423-448.

Stolp, H. and Gadkari, P. 1981. Non-pathogenic members of the genus, Pseudomonas. pp.719-741.In: Scher, F. (eds.). The Prokaryotes: A Handbook on Habitats, Isolation and Identification of Bacteria, Vol-I. Springer Verlag, Berlin.

Suneesh, K. 2004. Biodiversity of fluorescent pseudomonads in soils of moist deciduous forests of Western Ghats of Uttara Kannada district. M. Sc. thesis, University of Agricultural Sciences, Dharwad.

Suryakala, D., Maheshwaridevi, P. V. and Lakshmi, K. V. 2004. Chemical characterization and in vitro antibiosis of siderophores of rhizosphere fluorescent pseudomonads. Indian J. Microbiol., 44: 105-108.

Thomashow, L. S., Bonsall, R. F. and Weller, D. M. 1997. Antibiotic production by soil and rhizosphere microbes in situ. In: Hurst, C. J., Knudsen, G. R., McInerney, M. J., Stetzenbach, L. D. and Walter, M. V. (eds.). Manual of Environmental Microbiology. ASM Press, Washington, DC, pp 493-499.

Van Loon, L. C., Bakker, P. A. H. M. and Pieterse, C. M. J. 1998. Systemic resistance induced by rhizosphere bacteria. Annu.Rev.Phytopathol., 36: 453483.
Vanpeer, R. and Schippers, S. 1989. Plant growth and response to bacterization with selected Pseudomonas spp. strains and rhizosphere microbial development in hydroponic cultures. Can. J. Microbiol., 81: 728-734.

Vanpeer, R., Neimann, G. J. and Schippers, B. 1991. Induced resistance and phytoalexin accumulation in biological control of Fusarium wilt of carnation of Pseudomonas sp. WCS 4178. Phytopathol., 81: 728-734.

Voisard, C., Keel, O., Haas, P. and Defago, G. 1989. Cyanide production by Pseudomonas fluorescens helps to suppress black root rot of tobacco under gnotobiotic condition. Eur. Microbiol J., 8: 351-358.

Vrany, J. and Fiker, A. 1984. Growth and yield of potato plants inoculation with rhizosphere bacteria. Folia Microbiol., 29: 248-253.

Walley, F. L. and Germida, J. J. 1997. Response of spring wheat (Tritiucm aestivum) to interactions between Pseudomonas sp. and Glomus clarum NT-4. Biol. Ferti. Soils, 24: 365-371.

Weller, D., Raaijmakers, J. M., Gardener, B. B. M. and Thomashow, L. S. 2002. Microbial populations responsible for specific soil suppressiveness to plant pathogens. Annu. Rev. Phytopathol, 40: 309-348.

Whipps, J. M. 2001. Microbial interactions and biocontrol in the rhizosphere. J. Exp. Bot., 52: 487-511.

Zdor, R. E. and Anderson, A. J. 1992. Influence of root colonizing bacteria on the defense response of bean. Plant. Soil., 140: 99107.

\section{How to cite this article:}

Stanzin Dorjey, Disket Dolkar and Richa Sharma. 2017. Plant Growth Promoting Rhizobacteria Pseudomonas: A Review. Int.J.Curr.Microbiol.App.Sci. 6(7): 1335-1344. doi: https://doi.org/10.20546/ijcmas.2017.607.160 